\title{
Seed longevity and seeding strategies affect sagebrush revegetation
}

\author{
D. TERRANCE BOOTH
}

Author is Rangeland Scientist, USDA-ARS, High Plains Grassl. Res. Sta., 8408 Hildreth Road, Cheyenne, Wyo. 82009.

\begin{abstract}
Three hypotheses were tested relating to Wyoming big sagebrush (Artemisia tridentata Nutt. ssp. wyomingensis (Beetle and Young) revegetation on coal-mined land in Wyoming: (1) that fourwing saltbush (Atriplex canescens (Pursh) Nutt.) seeded > 2.2 kg pure live seed (pls)/ha would exclude sagebrush, (2) the contrasting view that the saltbush, as a "pioneer plant", facilitated sagebrush stand development [by promoting beneficial soil microbiological activity], and (3) that sagebrush stand development would be greater on fresh-stripped, than on stored, topsoil. The hypotheses were tested by comparing stand development on field plots: 1) seeded to sagebrush in February 1992, and March 1993 ; 2) fallowed in 1992, and sagebrush seeded in March 1993; 3) seeded to 'Wytana' fourwing saltbush in November, 1991, with sagebrush over-seeded in March, 1993, and; 4) no seeding. The experimental design was a randomized complete block with split plots of stored and fresh-stripped topsoil and with 3 replications. New sagebrush were detected annually through 4 post-seeding spring counts. Seed efficiency was affected by seeding strategy, but efficiency, density, and height were not affected by topsoil source. Proximity to saltbush did not affect sagebrush heights. The results imply that a 'Wytana' density $\leq 5$ seedlings $/ \mathrm{m}^{2}$ is unlikely to deter or promote development of the sagebrush stand, but it will significantly increase total-shrub seed efficiency and density. Seeding strategies, particularly pre-sowing fallow and mixed-species seedings, will likely have a greater influence on sagebrush revegetation than will topsoil source when topsoils are handled as they were in this study.
\end{abstract}

Key Words: Wyoming big sagebrush, fourwing saltbush, reclamation, fallow, early seral species, pioneer plants, ecological restoration, soil erosion

Sagebrush (Artemisia tridentata Nutt.) and other xerophytic shrubs are a conspicuous component of western North American

This work was supported in part by the Abandoned Coal Mine Lands Research Program at the University of Wyoming. Support was administered by the Wyoming Dept. of Environmental Quality from funds returned to Wyoming from the Office of Surface Mining of the U.S. Dept. of Interior. I thank Scott Belden, Environmental Coordinator, North Antelope Coal Mine for his cooperation and assistance; Drs. E.J. Depuit and G.E. Schuman for their part in preparing the grant proposal; Dr. G.V. Richardson who consulted on statistical design, analyses, and interpretation; L.W. Griffith, P.K. Freeman, J.R. Cockrell, C.L. Mahelona, E.M. Taylor, and M.C. Mortenson who provided technical assistance; and Drs. E.J. Depuit, E.D. McArthur, and R.D. Piper for their critical review of an earlier version of this report. Mention of trade names is for information only and does not imply an endorsement.

Manuscript accepted 7 May 01.

\section{Resumen}

Se probaron tres hipótesis relacionadas a la revegetación de minas de carbón en Wyoming con "Wyoming big sagebrush" (Artemisia tridentata Nutt. ssp. wyomingensis (Beetle and Young): (1) que el "Fourwing saltbush" (Atriplex canescens (Pursh) Nutt.) sembrado a una densidad $>\mathbf{2 . 2} \mathbf{k g}$ semilla pura viable/ha excluiría al "Sagebrush", (2) El punto de vista contrastante de que el "Saltbush",como una "planta pionera", facilitaría el desarrollo de la población de "Sagebrush"(al promover la actividad microbiológica benéfica del suelo) y (3) que el desarrollo de la población "Sagebrush" sería mayor en bandas de suelo superficial recién colocado (fresco) que en suelo almacenado. Las hipótesis se probaron comparando el desarrollo de poblaciones en parcelas de campo con los siguientes tratamientos: 1) "Sagebrush"sembrado en febrero de 1992 y Marzo de 1993; 2) barbechado en 1992 y "Sagebrush"sembrado en Marzo de 1993; 3) 'Wytana' fourwing saltbush"sembrado en Noviembre de 1991 y sobresembrado con "Sagebrush"en Marzo de 1993 y 4) parcelas testigo sin sembrar. El diseño experimental fue un bloques completos al azar en parcelas divididas en el que la parcela grande fue el tipo de suelo y se tuvieron 3 repeticiones. A través de 4 años después de la siembra, en los conteos anuales de primavera, se detectaron nuevas plantas de "Sagebrush". La eficiencia de la semilla fue afectada por la estrategia de siembra, pero la eficiencia, densidad y altura no fueron afectadas por la fuente de suelo. La proximidad de "Saltbush" no afecto la altura del "Sagebrush". Los resultados implican que una densidad de 'Wytana' $\leq 5$ plántulas $/ \mathrm{m}^{2}$ es improbable que impida o promueva el desarrollo de la población de "Sagebrush", pero incrementara significativamente la eficiencia total de la semilla del arbusto y la densidad. Las estrategias de siembra, particularmente el barbecho pre-siembra y las siembras de especies mezcladas, probablemente tendrá una mayor influencia en la revegetación de "Sagebrush" que la fuente de suelo, cuando las fuentes de suelo superficial son manejadas es manejado como en este estudio.

rangelands and provide key benefits to the function and utility of the ecosystems they occupy (McKell and Goodin 1973). For that reason they are encouraged, and in Wyoming are legally mandated (Federal Register 1996), for reclamation of coal-mined rangelands.

Several approaches have been tested for improving sagebrush establishment. These include sowing sagebrush and other shrubs without competing grasses, various surface seeding techniques, topsoil management (Monsen and Meyer 1990, Skilbred 1990, Schuman et al. 1998), sowing in combination with manipulated snow catchment, mulching, and sowing shrubs first and herbaceous plants later (Stevens et al. 1981, Brock 1982, Schuman et al. 1998). 
Two hypotheses dominated Wyoming big sagebrush (Artemisia tridentata Nutt. ssp. wyomingensis (Beetle and Young) revegetation discussions when this study was begun. The "exclusion" hypothesis stated that where fourwing saltbush (Atriplex canescens (Pursh) Nutt.) was seeded at $2.2 \mathrm{~kg}$ pure live seed (pls)/ha or greater rates, monotypic stands of that shrub would develop and exclude other shrubs, particularly sagebrush. The alternative or "pioneer plant" hypothesis held that poor soil physical characteristics and low levels of mycorrhizal innoculum in mined-land soils was the reason for poor stands of climax plants such as sagebrush (Booth 1985). Fourwing saltbush was recommended as an early seral species that could "...hasten the natural successional patterns" on New Mexico mined land by Wagner et al. (1978), and Booth (1985) postulated the shrub could function in that role in Wyoming. Meyer (1990) also suggested "pioneer" shrubs prepare reclaimed sites for later seral species. Therefore, I tested the "exclusion" and "pioneer" hypotheses on fresh-stripped and stored topsoil by monitoring sagebrush stands through 4 post-seeding growing seasons.

\section{Materials and Methods}

\section{Site Description and Preparation}

The research was conducted at the North Antelope Coal Mine, about $100 \mathrm{~km}$ south of Gillette, in Wyoming's Powder River Basin (43 $31^{\prime} 41^{\prime \prime} \mathrm{N}, 105^{\circ} 17^{\prime} 04^{\prime \prime} \mathrm{W}$ ). Precipitation in this continental climate ranges from 250 to $330 \mathrm{~mm}$ annually with $70 \%$ being received April-August (Table
1). Fresh topsoil was composed of a complex of loamy and clayey calcareous, mesic, shallow, Ustic Torrorthents (Schuman et al. 1998). The study was begun in August 1990, on 1/2 ha of leveled, regraded, and deep-ripped coal-mine spoil. Topsoil, which was either freshstripped or from a 5-year-old stockpile (designated as "stored"), was replaced to an average depth of $30 \mathrm{~cm}$, ripped, and disked (topsoil stockpiles were 10- to 15m-high mounds seeded to native cool-season grasses)(Schuman et al. 1998).

In late April 1991, 'Steptoe' barley (Hordeum vulgare L.) was seeded at $50 \mathrm{~kg}$ pls/ha to produce a stubble mulch over the entire study site. In mid-July the barley was mowed to remove seed heads.

\section{Seeding Strategy}

The sagebrush seeding-strategy plots were installed as follows (treatment symbols are indicated in parentheses): 1) sagebrush seeded in 1992, and in 1993 (ARTRx2), 2) fallow in 1992, sagebrush seeded in 1993 (Fallow-ARTR), 3) fourwing saltbush seeded in fall 1991, and sagebrush seeded in 1993 (ATCA-ARTR) and, 4) no seeding (Control).

The fourwing saltbush was 'Wytana' (Atriplex canescens Nutt. ssp. aptera (A. Nels.)), obtained from the Bridger Plant Materials Center, Bridger, Mont. The seed was harvested in 1986 and had $92.4 \%$ purity and $14 \%$ germination with a TZ test of $7 \%$ (tested 5 Oct. 1990). Total viability was counted as $14 \%$. 'Wytana' has 107,900 seeds/kg (J. Sheetz, personal communication) and was drilled at $26 \mathrm{~kg}$ pls/ha. The rate was equal to $2.6 \mathrm{~g} \mathrm{pls} / \mathrm{m}^{2}$ (281 live seeds $/ \mathrm{m}^{2}$ ) and was about 12 times greater than the $2.2 \mathrm{~kg}$ pls/ha suggested by some to be an upper limit above which the resulting saltbush stand would competitively exclude other shrubs (Booth 1985). However, 'Wytana' is a smaller shrub than most commercially available fourwing saltbush. [It is also well adapted to the extreme temperatures common to eastern Montana and Wyoming (Soil Conservation Service 1988).]

Sagebrush seed was collected locally (Powder River Basin) in December 1991. It was cleaned using a debearder (Booth et al. 1997) and a clipper cleaner as is the standard commercial practice. The purity was $52 \%$ and the germination was $74 \%$ (tag values). Sagebrush was broadcast late February 1992, at $2.4 \mathrm{~kg}$ pls/ha and midMarch 1993, at $2.0 \mathrm{~kg}$ pls/ha. Wyoming big sagebrush has 4.0 to 5.4 million seeds per kg (Meyer, In press). At 4 million seeds $/ \mathrm{kg}$, seeding rates would have dispersed 960 and 800 seeds $/ \mathrm{m}^{2}$ in 1992, and 1993, respectively. No perennial grasses were seeded on any of the plots.

\section{Data Collection \\ Sampling}

Shrub stand development was monitored in 1992 with 9, systematically located 1$\mathrm{m}^{2}$ quadrats in each treatment plot (Mueller-Dombois and Ellenberg 1974, p.74). Fifteen, $1-\mathrm{m}^{2}$ permanent quadrats were used in 1993 and thereafter. Shrubs were counted each spring (late April to early June). Counts were made by placing colored markers by each shrub as they were identified. The markers were counted, the plot photographed using $35 \mathrm{~mm}$ color-print film, and the markers recollected. The camera was equipped with a

Table 1. Monthly precipitation and mean monthly temperature, North Antelope Coal Company, Gillette, Wyo., 1992-1994. The 1978-1995 precipitation average is $32.3 \mathrm{~cm}$.

\begin{tabular}{|c|c|c|c|c|c|c|c|c|c|c|}
\hline \multirow[t]{2}{*}{ Month } & \multicolumn{2}{|c|}{1992} & \multicolumn{2}{|c|}{1993} & \multicolumn{2}{|c|}{1994} & \multicolumn{2}{|c|}{1995} & \multicolumn{2}{|c|}{1996} \\
\hline & Precip & Temp & Precip & Temp & Precip & Temp & Precip & Temp & Precip & Temp \\
\hline & $(\mathrm{cm})$ & $\left({ }^{\circ} \mathrm{C}\right)$ & $(\mathrm{cm})$ & $\left({ }^{\circ} \mathrm{C}\right)$ & $(\mathrm{cm})$ & $\left({ }^{\circ} \mathrm{C}\right)$ & $(\mathrm{cm})$ & $\left({ }^{\circ} \mathrm{C}\right)$ & $(\mathrm{cm})$ & $\left({ }^{\circ} \mathrm{C}\right)$ \\
\hline Jan & 0 & -0.6 & 0 & -7.2 & 0.20 & -3.3 & 0.05 & -2.2 & 0.03 & -7.8 \\
\hline Feb & 0.68 & 2.2 & 0.38 & -7.7 & 0.15 & -6.1 & 0.66 & -1.6 & 0.23 & -2.8 \\
\hline Mar & 3.15 & 4.4 & 1.47 & 2.2 & 0.41 & 3.3 & 0.97 & 0.6 & 0.56 & -2.8 \\
\hline Apr & 0.76 & 7.7 & 6.48 & 5.5 & 2.79 & 6.6 & 2.01 & 3.3 & 1.571 & 6.1 \\
\hline May & 2.26 & 13.2 & 5.94 & 12.7 & 2.87 & 14.9 & 8.94 & 8.3 & 12.171 & 8.9 \\
\hline Jun & 6.43 & 16.5 & 14.15 & 14.3 & 8.36 & 18.2 & 7.21 & 15.0 & 4.421 & 17.8 \\
\hline Jul & 7.75 & 17.6 & 9.70 & 17.1 & 4.93 & 19.8 & 1.68 & 20.0 & 0.711 & 21.1 \\
\hline Aug & 2.95 & 18.2 & 10.13 & 18.2 & 0.81 & 20.9 & 0.03 & 22.8 & 1.42 & 20.6 \\
\hline Sep & 1.75 & 15.4 & 2.29 & 12.1 & 1.22 & 16.0 & 0.23 & 13.9 & 2.24 & 13.3 \\
\hline Oct & 0.41 & 8.8 & 2.36 & 6.1 & 5.49 & 7.2 & 1.96 & 6.1 & 4.111 & 8.9 \\
\hline Nov & 0.89 & -0.6 & 0.36 & 6.1 & 5.49 & 7.2 & 0.10 & 4.4 & 0.25 & -2.2 \\
\hline Dec & $\underline{1.19}$ & -6.6 & $\underline{0.10}$ & -1.7 & $\underline{0.05}$ & -1.7 & $\underline{0}$ & -3.3 & $\underline{0.29}$ & -4.4 \\
\hline Total & 28.22 & & 53.36 & & 27.86 & & 23.84 & & 28.00 & \\
\hline
\end{tabular}

${ }^{1}$ Data recorded at Rochelle Mine due to sensor malfunction at North Antelope site. 
$28 \mathrm{~mm}$ lens and was mounted $1.5 \mathrm{~m}$ above the center of the plot.

The color prints were used to track seedling populations during the study period. Prints were scanned using a HewletPackard ScanJet 4C color scanner, then "MapInfo Professional" software (MapInfo Corporation, Troy, N.Y.) was used to map and monitor each seedling in all 360 quadrats for the 4 years that photographs were made.

\section{Seed Efficiency Analysis}

Seed efficiency is the number of live plants/unit of seed sown. I compared shrub seed efficiency as total shrubs (1996 count)/1,000 seeds and as number of sagebrush (1996 count)/1,000 seeds. Thus, seed efficiency reflects both seedling establishment and seedling survival. For these calculations I estimated sagebrush seeds at 4.0 million $/ \mathrm{kg}$ (Meyer In press) and used 107,900 seeds/kg for 'Wytana'.

\section{Shrub Density and Height Analysis}

Shrub density (total shrubs $/ \mathrm{m}^{2}$ ) was compared for 1996 without regard to seeding rates. Also for fall 1996, sagebrush height was measured for all plants in 1 , randomly-selected quadrat per seedingstrategy plot. Sagebrush in the ATCAARTR treatment were segregated according to those plants that were within, or outside, an arbitrary $7.6-\mathrm{cm}$ radius of a saltbush plant.

\section{Experimental Design and Statistical Analysis}

The experimental design was a randomized complete block with split plots and with 3 replications. Main plots were fresh and stored topsoil with seeding strategies randomly assigned within topsoils. Except for cohort analysis, the several statistical analyses used the "Mixed" procedure (SAS 1988, 1996, Littell et al. 1996). The "differences" option was used to compare least-square means.

Cohort counts within strategies across years were compared with confidence limits for the proportion, cohort count over the total of all cohorts, using the normal approximation (Steel and Torrie 1980, pages 478-479).

\section{Results and Discussion}

\section{Seed Longevity and Cohorts}

New sagebrush seedlings were detected from photographic data during all 4 annual counts made after March 1993. The pho-

Table 2. Count of live sagebrush in May, 1996, by age-class and seeding strategy, and test of cohort differences. Counts for 1993 include seedlings established in 1992 and 1993. Counts made fall of 1992 found 0.1 and 0.4 seedlings $/ \mathrm{m}^{2}$ in ARTRx2 fresh, and stockpiled topsoil. There were no sagebrush seedlings in any of the other plots in spring or fall of 1992.

\begin{tabular}{|c|c|c|c|c|c|}
\hline \multirow[b]{2}{*}{ STRATEGY } & \multicolumn{4}{|c|}{ COHORT (Year Detected) } & \multirow{2}{*}{$\begin{array}{c}\text { Total } \\
\text { All Cohorts }\end{array}$} \\
\hline & 1996 & 1995 & 1994 & 1993 & \\
\hline Fallow-ARTR ${ }^{1}$ & $42 c$ & $\begin{array}{l}-- \text { (to } \\
55 \mathrm{c}\end{array}$ & gebrus & $\left.t^{2}\right)-\cdots$ & \\
\hline & $42 \mathrm{C}$ & $35 \mathrm{c}$ & $297 \mathrm{a}$ & $144 \mathrm{~b}$ & 538 \\
\hline ARTRx2 & $42 \mathrm{~d}$ & $74 \mathrm{c}$ & $286 \mathrm{a}$ & $242 \mathrm{~b}$ & 644 \\
\hline ATCA-ARTR & $14 \mathrm{~b}$ & $46 b$ & $184 \mathrm{a}$ & $64 \mathrm{~b}$ & 308 \\
\hline Control & 0 & 1 & 0 & 0 & 1 \\
\hline \multicolumn{6}{|c|}{$\begin{array}{l}\text { Fallow-ARTR= plots fallowed in } 1992 \text { and seeded to sagebrush in } 1993 \text {; ARTRx2= sagebrush was seeded in } 1992 \text { and } \\
1993 \text {; ATCA-ARTR= 'Wytana' seeded in } 1992 \text { and sagebrush over-seeded in } 1993 \text {; and Control= not seeded. } \\
\text { Total for } 90 \text { quadrats. Cohort values within rows followed by the same letter are not significantly different at P } \leq 0.05 \\
\text { as tested by confidence limits for cohort/total proportions using the normal approximation (Steel and Torrie } 1980 \text { ). The } \\
\text { Control was not tested due to lack of variance among years; confidence intervals for seeding strategies did not include } 1 \\
\text { or } 0 \text {. This implies that all other strategies were significantly greater than the Control and is the only valid comparison } \\
\text { among strategies. }\end{array}$} \\
\hline
\end{tabular}

tographs also show that each cohort population-including the cohort resulting from the 1996 germination-was significantly greater than the control for all strategies (Table 2). Only 1 sagebrush was found among all unseeded plots in the study, evidence that; (1) the annual appearance of new seedlings in seeded plots did not result from natural seed dispersion and, (2) fresh-stripped topsoil did not act as a seed source.

Young and Evans (1989) reported basin big sagebrush (Artemisia tridentata Nutt. ssp. tridentata) did not maintain seed viability for more than a few months. However, seed dormancy in Wyoming big sagebrush may contribute to greater seed longevity (McDonough and Harniss 1974, Booth et al. 1997). This is the first study to measure the effect of Wyoming big sagebrush seed dormancy on seedling emergence from the soil, and to document the appearance of new seedlings during 4 annual post-seeding counts.

The 1994 cohort was the largest (Table 2). This was likely due to favorable 1993 weather (Table 1). Many seedlings likely established during the cool, wet, 1993 spring but remained too small to detect in 1993. Or, there may have been considerable 1993 post-count seedling establishment. In either case, the pulse in seedling establishment is consistent with other

Table 3. Means for the sagebrush-only, seed efficiency analysis $(P=0.15$ for differences among seeding strategies). Seeding-strategy symbols are as described in Table 2.

\begin{tabular}{lcc}
\hline \hline $\begin{array}{l}\text { Seeding } \\
\text { trategy }\end{array}$ & Number sagebrush & $\begin{array}{c}\text { Mean separations among } \\
\text { seeding strategies }\end{array}$ \\
\hline & (mean/1,000 seeds) & Fallow-ARTR vs. ARTRx2 $\mathrm{P}=0.08$ \\
Fallow-ARTR & 7.5 & ARTRx2 vs. ATCA-ARTR $\mathrm{P}=0.82$ \\
ATCA-ARTR & 4.3 & ATCA-ARTR vs. Fallow-ARTR $\mathrm{P}=0.11$ \\
ARTRx2 & 3.9 & \\
\hline
\end{tabular}

reports of thick stands of sagebrush establishing with favorable weather conditions (Lommasson 1948, Went 1955, Booth et al. 1999).

\section{The Need to Seed} plots (Table 2) is evidence of the need to seed shrubs, even on fresh-stripped topsoil. Howard and Samuel (1979) found < 0.1 sagebrush, and $<0.4$ total-shrub seedlings $/ \mathrm{m}^{2} 1$ year after fresh-stripped topsoil was spread at Kemmerer, Wyoming. Approximately the same result was obtained at Oak Creek, Colo. (Howard and Samuel 1979). These are unacceptably low densities (Federal Register 1996) for mines in shrub-dominated landscapes.

\section{Benefits of High Sagebrush Seeding Rates}

The ARTRx2 (sagebrush seeded in 1992, and in 1993) total seeding rate was $4.4 \mathrm{~kg} / \mathrm{ha}$ or $1,760 \mathrm{seeds} / \mathrm{m}^{2}$ and it produced the most sagebrush by the all-cohort count (Table 2). For comparison, FallowARTR (fallow in 1992, sagebrush seeded in 1993) was seeded at 800 seeds $/ \mathrm{m}^{2}(2.0$ $\mathrm{kg} / \mathrm{ha}$ ). Booth et al. (1999) reported a linear relationship between shrub densities of old ( $>10$ years) stands and shrub seeding
The lack of shrubs on unseeded control 


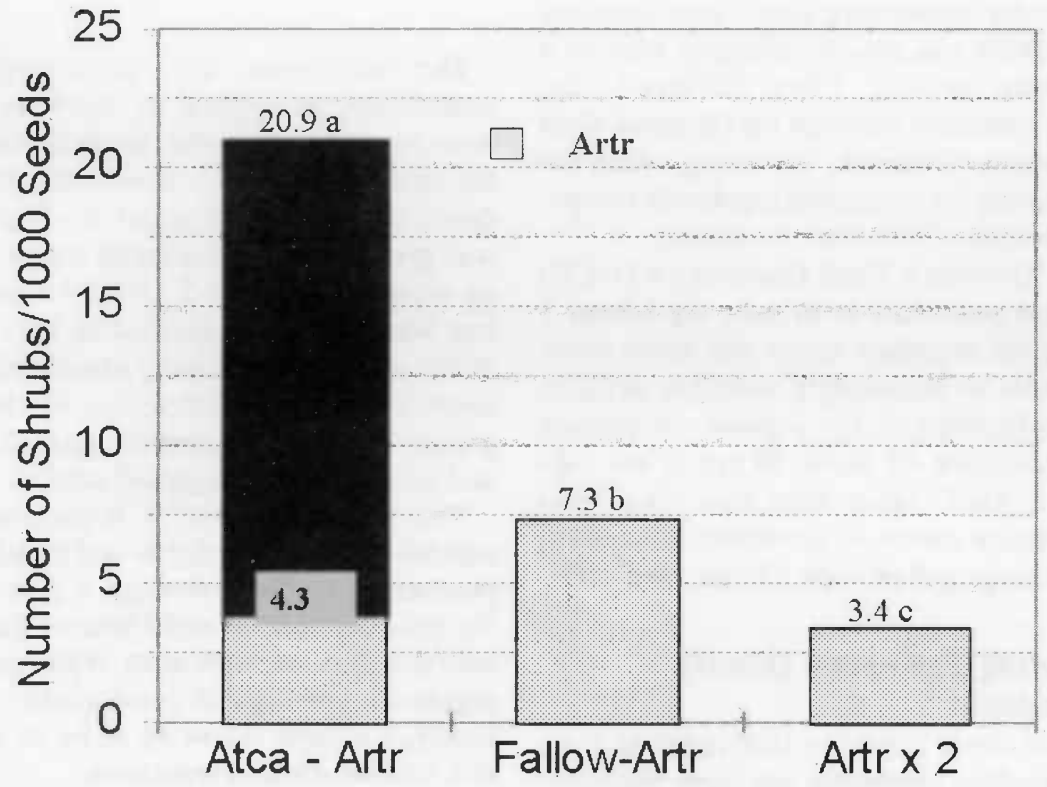

Fig. 1. Seed efficiency as shrubs (1996 count)/1,000 seeds by seeding strategy. Means followed by the same letter are not different at $P<0.001$ for ATCA-ARTR versus all other values, and at $\mathbf{P}=0.10$ for Fallow-ARTR versus ARTRx2. The seed efficiency of sagebrush within the ATCA-ARTR treatment is given for reference. Shrub seeding strategies and symbols are: ARTRx2 = sagebrush was seeded in 1992 and 1993; Fallow-ARTR = fallowed in 1992 and seeded to sagebrush in 1993; ATCA-ARTR = 'Wytana' saltbush seeded in 1992 and sagebrush over seeded in 1993, ATCA = 'Wytana' fourwing saltbush, ARTR = sagebrush. Data were calculated using 107,930 'Wytana' seeds/kg (J. Sheetz, personal communication) and 4.0 million Wyoming big sagebrush seeds/kg (Meyer, In press).

rates up to 1,000 seeds $/ \mathrm{m}^{2}$ for shrub-seed mixtures containing Wyoming big sagebrush. They recommended the 1,000 seeds $-/ \mathrm{m}^{2}$ rate $(2.5 \mathrm{~kg} / \mathrm{ha})$ for mixtures with Wyoming big sagebrush. These data support that recommendation.

\section{Seed Efficiency as affected by Seeding Strategy and Topsoil Management}

The ATCA-ARTR (fourwing saltbush seeded in fall 1991, sagebrush seeded in 1993) strategy had the greatest seed efficiency (total shrubs/1,000 seeds) and was the most consistently successful strategy (Fig. 1). The success of mixed-shrub seedings was also reported by Booth et al. (1999). Fallow-ARTR was the second most efficient strategy and ranked first when only sagebrush was considered (Fig. 1 and Table 3 ).

Lack of a difference in sagebrush seed efficiency between ARTRx2 and ATCAARTR (Table 3), suggests "Wytana" had no measurable effect (positive or negative) on sagebrush establishment and survival. Although 1993 precipitation was $165 \%$ of average, the remaining years of the study had below average precipitation (Table 1). considered important because (1) interactions are more likely to show significance since they combine main effects, and (2) there is no consistent pattern among means (Table 4). Saltbush density averaged 5.0 shrubs $/ \mathrm{m}^{2}$ in the ATCA-ARTR treatments.

Table 4. Total shrub density (shrubs/m2) by topsoil and seeding strategies (topsoil $\mathrm{x}$ seeding strategy $P=0.12$ ). Differences among means are not significant. Seeding strategy symbols are as described in Table 2.

\begin{tabular}{lcc}
\hline \hline Topsoil & Seeding Strategy & Density \\
\hline \multirow{3}{*}{ Stored } & & $\left(\right.$ Shrubs $\left./ \mathrm{m}^{2}\right)$ \\
& ARTRx2 & 10.2 \\
& F-ARTR & 4.9 \\
Fresh & ATCA-ARTR & 7.7 \\
& ARTRx2 & 4.6 \\
& F-ARTR & 8.3 \\
& ATCA-ARTR & 9.5 \\
\hline
\end{tabular}

Sagebrush Heights Not Affected by

Seeding Strategy, Topsoil

Management, or Proximity to

Saltbush

Heights of sagebrush plants did not vary by seeding strategy $(\mathrm{P}=0.91)$, topsoil $(\mathrm{P}=$ $0.57)$, the interaction ( $P=0.87$ ), or proximity to 'Wytana' fourwing saltbush ( $\mathrm{P}=$ 0.56) (Table 5).

\section{Soil Erosion}

The annual photographs of 360 quadrants systematically located throughout the study area are a reliable record of soil surface conditions during the study. The photographs show barley straw remained on the plots through 1995, though by that time many perennial grasses and forbs were present. Erosion rills and soil pedestals do not appear in the photographs, nor were they noted when field data were collected.

\section{Shrub Density Not Affected by Seeding Strategy or Topsoil Management}

Shrub density (shrubs $/ \mathrm{m}^{2}$ ) was not affected by seeding strategies $(P=0.62)$ or topsoil management $(\mathrm{P}=0.97)$. The interaction was $P=0.12$. This interaction is not

\section{Summary of Topsoil Results}

There were no differences between fresh stripped and stored topsoil for any test variable $(P=0.57$ for sagebrush height

Table 5. Sagebrush mean height $(\mathrm{mm})$ by seeding strategy, topsoil source, and distance from "Wytana" fourwing saltbush. Means are not different ( $P$ values $\geq 0.56)$. Seeding-strategy symbols are as described in Table 2.

\begin{tabular}{lccccc}
\hline \hline $\begin{array}{l}\text { Seeding } \\
\text { Strategy }\end{array}$ & $\begin{array}{c}\text { Sagebrush } \\
\text { height }\end{array}$ & Topsoil & $\begin{array}{c}\text { Sagebrush } \\
\text { height }\end{array}$ & $\begin{array}{c}\text { 'Wytana' } \\
\text { distance }\end{array}$ & $\begin{array}{c}\text { Sagebrush } \\
\text { height }\end{array}$ \\
\hline & $(\mathrm{mm})$ & Stored & 54 & $\leq 7.6 \mathrm{~cm}$ & 43 \\
ARTRx2 & 48 & Fresh & 48 & $>7.6 \mathrm{~cm}$ & 55 \\
Fallow-ARTR & 51 & 53 & & & \\
ATCA-ARTR & 53 & & & \\
\hline
\end{tabular}


was the lowest observed significance level of any test of topsoil effects). This was unexpected since the fresh-stripped topsoil contained greater numbers of vesicular mycorrhizae spores (Schuman et al. 1998). Also, Stahl et al. (1998) have shown in greenhouse studies that mycorrhizaeinfected sagebrush seedlings survive greater drought stress than non-mycorrhizal seedlings. The reasons topsoil had no effect may be partly due to soil surface variation among the plots and replications. During 1993-1994 (see precipitation data in Table 1) parts of the study area subsided as much as $30 \mathrm{~cm}$.(estimated), resulting in flow-patterns across plots and replications and decreasing site uniformity. Lack of a topsoil effect may also have been due to the management of the storedtopsoil (Schuman et al. 1998).

Whatever the reasons, detecting an effect from topsoil under field conditions was difficult even with uniform plots. In the adjacent study (Schuman et al. 1998), soil surfaces remained uniform but sagebrush densities on fresh-stripped topsoil were significantly greater $(\mathrm{P}<0.10)$ than those on stored topsoil only where grass was not seeded (Table 2 and text, page 226, in Schuman et al. 1998).

The high sagebrush seed efficiency and shrub densities $\geq 1 / \mathrm{m}^{2}$ occurred on both types of soils, suggesting that micro-site moisture differences had a greater influence on sagebrush seedling establishment than did topsoil source; and, that stored topsoil, managed as in this study, will support dense stands of sagebrush (Table 4).

\section{Fallowing and Shrub Stand Establishment}

The Fallow-ARTR strategy produced significantly $(\mathrm{P}=0.10)$ more surviving shrubs/1,000 seeds (1996 count) than were produced by the ARTRx 2 strategy. Although the effect of this seeding strategy for the sagebrush-only analysis was marginally significant $(\mathrm{P}=0.15)$, there are reasons to believe the strategy was as effective for sagebrush alone as for the 2 shrubs together.

Shrubs have extensive root systems that utilize moisture deep in the soil profile (West and Tueller 1972, Anderson et al. 1972) and fallowing is an effective means of replenishing that soil moisture. This is especially true for topsoiled areas protected by stubble mulch (Schuman et al. 1980, Schuman and Powers 1981). It is logical to conclude that a fallowing strategy would increase the seed efficiency of all shrubs and I recommend it be tested in other situations for promoting shrub revegetation. Fallowing can also be effective without a stubble mulch. Chet Skilbred, Sr. Environmental Scientist for Glenrock Coal Company, Glenrock, Wyoming, offers the following for successful sagebrush revegetation (Nov. 1998 letter to author).

"Glenrock Coal Company's (GCC) field procedure is to deep rip (about 1 m) the regraded spoils and allow these spoils to accumulate moisture prior to application of the topsoil. Following application of about $76 \mathrm{~cm}$ of the topsoil, GCC again deep rips. This field practice seems to accelerate (moisture) recharge and provide a better seedbed."

\section{Meeting The Shrub Density \\ Standard}

The shrub densities that resulted from the seeding treatments are more than adequate to meet wildlife needs and environmental law (Table 4, Federal Register 1996). While I acknowledge the influence of 1993's favorable weather in producing high shrub densities, I also believe revegetation procedures that produced up to 10 times greater-than-required shrub densities (Table 4) with favorable weather, will be useful when weather patterns are less favorable.

There are several findings of this study that have application for meeting the Wyoming shrub density standard. One, there is the probable increase in seed efficiency from fallowing. Two, use of stubble-mulch-protected fallow with high Wyoming big sagebrush seeding rates $(2.5$ $\mathrm{kg} / \mathrm{ha}$ ) in a mix with other shrubs such as 'Wytana' is likely to result in synergistic increases in shrub densities. Three, as demonstrated by this study, high seeding rates for Wyoming big sagebrush are important for seeding-year establishment and to create a soil seed bank that may produce significant populations of new seedlings annually for 4 post-seeding growing seasons (Table 2). Four, as demonstrated by this study, seeding sagebrush with 'Wytana', where the 'Wytana' density is $\leq 5$ seedlings $/ \mathrm{m}^{2}$, is unlikely to hinder sagebrush stand development. Where 'Wytana' was seeded with sagebrush the mixed-shrub stand was $43 \%$ sagebrush and the difference in total-shrub density equaled 10,000 more 1996shrubs/ha than resulted from the doubleseeding strategy, ARTRx2.

\section{Conclusions}

The "exclusion" and "pioneer-plant" hypotheses, as applied to fourwing saltbush on coal-mined land, are both rejected for lack of evidence. I also found no evidence that sagebrush stand development was greater on fresh-stripped topsoil than on topsoil stored for 5 years. I conclude that where soils are handled as they were in this study, the variability associated with micro-site moisture differences will have a greater effect on sagebrush establishment and survival than will topsoil source.

The soil-seed bank of Wyoming big sagebrush remained viable and capable of producing seedlings through 4 post-seeding growing seasons and I believe that situation will occur with most Wyoming big sagebrush seedings of good quality seed. Lastly, I believe fallowing to be an effective tool for shrub revegetation.

\section{Literature Cited}

Anderson, D.J., R.A. Perry, and J.H. Leigh. 1972. Some perspectives on shrub / environment interactions, p. 172-181. In: C.M. McKell et al.(eds), Proc. wildland shrubs their biology and utilization, July 1971, Logan, Ut., Intermount. Forest and Range Exp. Sta., Gen. Tech. Rep. INT-1, Forest Serv., Ogden, Ut.

Booth, D.T. 1985. The role of fourwing saltbush in mined land reclamation: a viewpoint. J. Range Manage. 38:562-565.

Booth, D.T., Y. Bai, and E.E. Roos. 1997. Preparing sagebrush seed for market: effects of debearder processing. J. Range Manage. 50:51-54

Booth, D.T., J.K. Gores, G.E. Schuman, and R.A. Olson. 1999. Shrub densities on pre1985 reclaimed mine lands in Wyoming. J. Restoration Ecol. 7:1-9.

Brock, J.H. 1982. Interseeding and interplanting techniques for southwest reclamation, p.192-195. In: E.F. Aldon and W.R. Oaks (eds), Proc. reclamation of mined lands in the Southwest, Oct. 1982, Albuquerque, N.M., New Mexico Chapter Soil Conserv. Soc. Amer., Albuquerque, N.M.

Federal Register. 1996. Office of Surface Mining and Enforcement. 30 CFR Part 950. Wyoming Regulatory Program - final rule; approval of amendment. 61 (152):40735.

Howard, G.S. and M.J. Samuel. 1979. The value of fresh-stripped topsoil as a source of useful plants for surface mine revegetation. J. Range Manage. 32:76-77.

Littell, R.C., G.A. Milliken, W.W. Stroup, and R.D. Wolfinger. 1996. SAS system for mixed models. SAS Inst. Inc., Cary, N.C.

Lommasson, T. 1948. Succession in sagebrush. J. Range Manage. 1:19-21 (reprinted in Rangelands 15 (1993):109-110). 
McDonough, W.T. and R.O. Harniss. 1974. Effects of temperature on germination in three subspecies of big sagebrush. J. Range Manage. 27:204-205.

McKell, C.M. and J.R. Goodin. 1973. United States arid shrublands in perspective, $\mathrm{p}$. 12-18. In: Proc. 3rd Workshop of U.S. Australia Rangelands Panel, Tucson, Arizona. Soc. for Range Manage. Denver, Colo.

Meyer, S.E. 1990. Shrubland restoration-an ecologist's perspective. Handout: Workshop on plant species and wildlife habitat establishment successes and failures. Billings, Mont. USDA Forest Service, Intermountain Research Station, Shrub Sci. Lab., Provo, Ut.

Meyer, S.E. In press. Artemisia. In: F. Bonner and S. Krugman (eds). Woody plant seed manual, $3^{\text {rd }}$ edition. USDA-Forest Service. (electronic pre-print available at: http://www.wpsm.net/Genera.htm\#e)

Monsen, S.B. and S.E. Meyer. 1990. Seeding equipment effects on establishment of big sagebrush on mine disturbances, p. 192-199. In: Proc. $5^{\text {th }}$ Billings symposium on disturbed land rehabilitation, Mar. 1990, Billings, Mont., (Vol. I), Reclam. Res. Unit. Pub. No 9003, Montana State Univ., Bozeman, Mont.
Mueller-Dombois, D. and H. Ellenberg. 1974. Aims and methods of vegetation ecology. John Wiley and Sons, N.Y.

SAS. 1988. SAS/STAT user's guide, release 6.03 Edition. SAS Inst. Inc., Cary, N.C.

SAS. 1996. SAS/STAT software: changes and enhancements through release 6.11. SAS Inst. Inc., Cary, N.C.

Schuman, G.E. and J.F. Power. 1981. Topsoil management on mined lands. J. Soil and Water Conserv. 36:77-78.

Schuman, G.E., D.T. Booth, and J.R. Cockrell. 1998. Cultural methods for establishing stands of Wyoming big sagebrush on mined lands. J. Range Manage. 51:223-230.

Schuman, G.E., E.M. Taylor, Jr., F. Rauzi, and G.S. Howard. 1980. Standing stubble versus crimped straw mulch for establishing grass cover on mined lands. J. Soil and Water Conserv. 35:25-27.

Skilbred, C.L. 1990. Direct seeding of sagebrush species on regraded mine lands in east central Wyoming. Handout: Workshop on plant species and wildlife habitat establishment successes and failures, Billings, Mont. Glenrock Coal Co., Glenrock, Wyo.

Soil Conservation Service (SCS). 1988. Plant materials handbook. Distributed by US Dept. of the Interior, Office of Surface Mining, Reclamation and Enforcement.
Stahl, P.D., G.E. Schuman, S.M. Frost, and S.E. Williams. 1998. Arbuscular mycorrhizae and water stress tolerance of Wyoming big sagebrush seedlings. Soil Sci. Soc. Amer. J. 62:1309-1313.

Stevens, R., W.L. Moden, and D.W. McKenzie 1981. Interseeding and transplanting shrubs and forbs into grass communities. Rangelands 2:55-58.

Steel, R.G.D. and J.H. Torrie. 1980 . Principles and procedures of statistics. McGraw-Hill Book Company, N.Y.

Wagner, W.L., W.C. Martin, and E.F. Aldon. 1978. Natural succession on stripmined lands in northwestern New Mexico. Reclamation Rev. 1:67-73

Went, R.W. 1955. The ecology of desert plants. Scientific Amer. 192:68-75.

West, N.E. and P.T. Tueller. 1972. Special approaches to studies of competition and succession in shrub communities, p. 165-171. In: C.M. McKell et al. (eds), Proc. wildland shrubs - their biology and utilization, July 1971, Logan, Ut., Intermount. Forest and Range Exp. Sta., Gen. Tech. Rep. INT-1, Forest Serv., Ogden, Ut.

Young, J.A. and R. Evans. 1989. Dispersal and germination of big sagebrush (Artemisia tridentata) seeds. Weed Sci.37:201-206. 